\title{
Når det hellige og det verdslige rum smelter sammen
}

\author{
Danske kirker i udlandet og en dansk offentlig sfære
}

\author{
MARGIT WARBURG
}

ENGLISH ABSTRACT: From a sociological perspective, Danish churches abroad are like other immigrant religious institutions. In addition to holding services in a Danish setting, the churches also fulfil many of the social needs of the immigrant community. The many secular activities mean that the churches do not always maintain a distinct separation between sacred and profane space. Examples from Danish churches in Argentina and Rotterdam illustrate that this may challenge popular notions of the importance of separating sacred space from profane space. The Danish state and Danish business play a central role in the everyday life of several of the churches abroad, and a church such as the Danish seamen's church in Singapore has developed to become a local Danish public sphere, servicing the about 1,500 Danish residents in Singapore.

DANSK RESUMÉ: Danske kirker i udlandet ligner i sociologisk henseende andre indvandrersamfunds religiøse institutioner, idet udlandskirkerne foruden at danne ramme om et dansk-præget kirkeliv i høj grad også dækker mange af immigrantsamfundenes sociale behov. De mange verdslige aktiviteter betyder, at kirkerne ikke altid opretholder en skarp adskillelse mellem det hellige og det verdslige rum. Eksempler fra danske kirker i Argentina og Rotterdam illustrerer, at det kan udfordre folkelige opfattelser af det betydningsfulde $i$ at holde helligt rum adskilt fra verdsligt rum. Den danske stat og dansk erhvervsliv spiller en central rolle iflere af udlandskirkernes hverdag, og en udlandskirke som den danske sømandskirke i Singapore har udviklet sig til en lokal dansk offentlig sfxre for de ca. 1.500 fastboende danskere i Singapore.

KeYwords: Danish churches abroad, sacred versus profane, immigrants, public sphere, state and church. 
Adskillige sociologiske studier af religion og migration har vist, at immigranter som regel danner religiøse foreninger baseret på deres egen nationale baggrund frem for at tilslutte sig eksisterende religiøse institutioner i det nye værtsland (Baumann 1995: 218-223, 322-324, 409-414; Warner 1998a; Warner 1998b; Yang \& Ebaugh 2001; Ballard 2003; Kühle 2006; Levitt 2007). Afvigelser fra dette mønster forekommer først og fremmest i de tilfælde, hvor immigranterne er medlemmer af religiøse minoriteter, som er en del af et bredere, tværnationalt netværk, der omfatter andre nationaliteter. Her er der sjældent et tilstrækkeligt antal tilhængere lokalt blandt immigranterne til, at de kan danne deres egne, nationalt baserede menigheder, og de søger derfor ind i eksisterende menigheder. Det er for eksempel tilfældet med pinsebevægelsens kirker (Levitt 2004).

Immigranter opretter naturligvis også andre foreninger baseret på nationalitet såsom selskabelige foreninger og sportsklubber, men kirker, moskeer, synagoger og templer er vigtige mødesteder for nye indvandrere, og her etablerer de ofte deres første kontakter med andre landsmænd (Yang \& Ebaugh 2001). Religionssociologer forklarer dette mønster med, at de fleste immigranter har behov for støtte gennem sociale netværk i deres nye land. Her fungerer immigranternes trossamfund som et sted, hvis indretning og funktion virker bekendt, og hvor immigranterne kan være sammen med deres egne uden særlige begrænsninger.

For at opfylde behovene i indvandrersamfundet udvider immigranternes religiøse institutioner ofte deres aktiviteter til at omfatte mere end blot traditionelle gudstjenester. De udvikler sig typisk til at blive sociale rum med flere formål, som danner ramme om forskellige, ikke-religiøse aktiviteter som for eksempel sprogundervisning, verdslige fester, sportsudøvelse, selskabelige sammenkomster og andre fritidsaktiviteter (Yang \& Ebaugh 2001). Mange af disse aktiviteter giver immigranterne ekstra social kapital såsom nyttige forbindelser og tilbud om arbejde, og derved bliver det lettere for immigranterne at slå sig ned i det nye modtagerland (Hirschman 2004). Charles Hirschman udtrykker det sådan, at indvandreres religiøse institutioner tilbyder deres medlemmer tre andre ting ud over religion, nemlig refugium (tilflugtssted), ressourcer og respektabilitet (Hirschman 2004).

Meget af den teoretiske forståelse af immigranters religiøse institutioner og deres sociale rolle er baseret på især amerikanske studier af forskellige, ikke-vestlige immigrantgrupper og deres integration i modtagersamfundet. Men disse grupper udgør ikke noget særtilfælde, for historisk set udnyttede de europæiske immigranter, der udgjorde den store immigrationsbølge for hundrede år siden, også deres kirker og synagoger på lignende måder som et led i at tilpasse sig det amerikanske samfund (Herberg 1960; Simonsen 1990).

Med udgangspunkt i materiale fra mine studier af danske kirker i udlandet vil jeg diskutere deres funktion og brug blandt danske immigranter og vise, at vægtningen mellem de religiøse og de verdslige aktiviteter tilsyneladende hælder ganske meget 
over mod den verdslige side. ${ }^{1}$ I en dansk kirke i udlandet er der typisk ikke nogen skarp adskillelse mellem det hellige og det verdslige rum, og de smelter sammen til et fælles dansk, nationalt-religiøst rum. Denne sammensmeltning kan af og til udfordre folkelige opfattelser omkring vigtigheden af at holde helligt rum adskilt fra verdsligt rum.

Indretningen og brugen af dette national-religiøse rum påvirkes af flere andre aktører end præsten og medlemmerne af kirkens bestyrelse. Gennemførelsen af de forskellige verdslige aktiviteter kræver en aktiv deltagelse fra mange mennesker, og de fleste af dem arbejder som frivillige uden løn. Det kirkelige medlemskontingent er ikke stort nok til at dække driftsomkostningerne, og kirkerne er nødt til at engagere sig i forskellige kommercielle aktiviteter og opnå støtte fra virksomheder, som kan tænkes at være interesserede i kirkens arbejde. En dansk kirke i udlandet er derfor afhængig af støtte fra både borgerne og erhvervslivet, hvilket også er det typiske mønster for langt størstedelen af protestantiske menigheder i for eksempel USA. Den danske stat er dog en yderligere, vigtig aktør, også økonomisk, hvilket er usædvanligt for immigrantkirker. På grund af statens vigtige rolle vil jeg argumentere for, at danske kirker i udlandet repræsenterer en særlig sammensmeltning af den danske stats, civilsamfundets og erhvervslivets interesser, hvorved de deler vigtige karaktertræk med en offentlig sfære i Jürgen Habermas' opfattelse.

\section{Danskere i udlandet - en privilegeret, sekulariseret immigrantgruppe}

Nutidens danske immigranter i udlandet adskiller sig fra de fleste andre, mindre begunstigede immigrantgrupper, som traditionelt er dem, der især studeres af antropologer og sociologer. De danskere, der emigrerer i dag, er som regel forholdsvis velhavende, mange erklærer sig for at være ikke-troende, og kun et mindretal var aktive kirkegængere, da de boede i Danmark (Jacobsen \& Warburg 2011). En stor del af dem er desuden ikke udvandret permanent, men sigter på en tilbagevenden til Danmark.

Udvandringen fra Danmark påvirker dog kirkegangsmønsteret. En kollega og jeg har i en omfattende, kvantitativ undersøgelse blandt danskere i udlandet vist, at hyppigheden af kirkegang stiger væsentligt efter emigrationen. ${ }^{2}$ Særligt bemærkelsesværdig er ændringen i kirkelig adfærd blandt dem, der sandsynligvis ikke går i kirke, fordi de er troende, nemlig de 46 pct. af danskerne i udlandet, der svarede, at de ikke troede

1 Materialet er indsamlet gennem feltbesøg til danske kirker i udlandet, blandt andet danske kirker i Argentina, Rotterdam og Singapore. Jeg takker Forskningsrådet for Kultur og Kommunikation samt Det Strategiske Forskningsråd, projektet Alternative Spaces, for støtte til gennemførelse af disse besøg. Dele af denne artikel er baseret på et bogkapitel, som er skrevet i forbindelse med afslutningen af Alternative Spaces (Warburg under udgivelse).

2 I denne undersøgelse, Religion blandt danskere $i$ udlandet 2009, fik vi svar fra flere end 1.100 svarpersoner fra hele verden (Jacobsen \& Warburg 2011). 
på Gud. Vi fandt frem til, at kun 1 pct. af de ikke-troende (6 ud af 437) regelmæssigt gik i kirke, da de boede i Danmark før deres udvandring. Med "regelmæssigt" mener vi en gang om måneden eller oftere. Dette resultat, der næppe kan komme som den store overraskelse, er i overensstemmelse med resultaterne fra Den Europæiske Værdiundersøgelse 2008, der viste, at kun 1 pct. af de danskere i Danmark, der ikke tror på Gud, regelmæssigt går i kirke (6 ud af $511=1$ pct.). Men efter udvandringen stiger procentdelen af de danskere, der ikke tror på Gud og alligevel går i kirke regelmæssigt, til 5 pct. (21 ud af 437), og det er statistisk signifikant.

\section{De danske kirkers sociale funktion}

På baggrund af ovenstående resultater er det oplagt at stille spørgsmålet: Hvad kan motivere folk til at begynde at gå i kirke regelmæssigt, når de samtidig hævder, at de ikke tror på Gud? Det illustreres måske bedst af svaret fra en informant, der fortalte mig om hendes motiver til at gå i den danske sømandskirke i Rotterdam:

Jeg er slet ikke religiøs, og jeg går aldrig i kirke i Danmark. Men det gjorde jeg, da jeg boede et år i Rotterdam. Jeg syntes, det var rart at være sammen med andre danskere, så var jeg ikke "den anden" i det hollandske samfund, og hollænderne blev for en gangs skyld selv "de andre". ${ }^{3}$

Hun er tydeligvis ikke alene om dette motiv. Den kvantitativt betydelige ændring i adfærd blandt udtrykkeligt ikke-troende danskere afspejler, at de danske kirker i udlandet - ligesom andre immigranters religiøse institutioner - tydeligvis opfylder en bredere funktion som et dansk socialt og kulturelt mødested, end kirkerne gør i Danmark.

Materialet fra mine feltstudier af danske kirker i udlandet bekræfter denne konklusion, og det er den danske sømandskirke i Singapore også et godt eksempel på. Kirken blev grundlagt i 1985 og flyttede hurtigt efter ind i en nedslidt villa i kolonistil, hvorefter frivillige blandt de fastboende danskere i Singapore renoverede og nyindrettede den til kirke (Pedersen 2010). Ud over dens primære funktion som sømandskirke er kirken vokset til at blive en slags sognekirke for de nu omkring 1.500 registrerede fastboende danskere i Singapore. ${ }^{4}$

En undersøgelse fra 2006 foretaget af præsten Hans Vestergaard Jensen viser, hvor vigtig kirken er som et dansk samlingssted i Singapore (Jensen 2006). Han sendte et spørgeskema pr. e-mail ud til alle registrerede danske familier i Singapore i 2006. 50 pct. svarede, hvilket er en forholdsvis god svarprocent. 76 pct. af svarpersonerne havde

3 Interview med en 40-årig kvinde, 23. juni 2009.

4 Tal for 2010 fra den danske ambassadør i Singapore, se www.ambsingapore.um.dk/en/menu/AboutUs/ Ambassadors+Greeting/ (set 28.6.2011). 
boet i Singapore i mere end et år og en tredjedel i mere end 5 år. Langt størstedelen af svarpersonerne brugte kirken: Kun 8 pct. havde aldrig været der; til gengæld havde to tredjedele været der mindst fire gange på et år. Disse tal viser, at kirken betjener et bredt udvalg af de danskere, der bor i Singapore. Faktisk er den danske sømandskirke i Singapore det vigtigste danske samlingssted i Singapore, som regelmæssigt er åbent for alle danskere.

De mest populære blandt kirkens arrangementer og dem, som svarpersonerne følte, var mest relevante, var interessant nok ikke gudstjenesterne om søndagen, men fælles arrangementer som julebasar, juletræsfest, sankthans, fastelavn og grundlovsdag. Disse arrangementer hører på ingen måde til den evangelisk-lutherske kirkes kerneydelser, men det er traditionelle begivenheder, hvor danskere samles. Det samme kan siges om kirkens udflugter, fodboldturneringer og månedlige aftener med forelæsninger, diskussioner og kaffe (Jensen 2010).

Et af kirkens populære arrangementer er et kaffebord hver tirsdag morgen. Mellem tyve og tredive personer møder op og drikker kaffe; de er alle kvinder, som er gift med danske mænd, der er udstationeret $i$ et par år eller længere. Ved kaffebordet er de midlertidigt isoleret fra det singaporeanske samfund og bruger et par timer sammen i en helt igennem dansk gruppe. Her udveksler kvinderne nyheder, diskuterer problemer eller videregiver gode råd om at være udlænding i Singapore. En tidligere præst og hans kone udtrykte det således: "Det bliver lige pludselig lidt nemmere at være 'medfølgende' [ægtefælle], når man ikke er alene om det" (Pedersen \& Pedersen 2010: 41). I den henseende kan danske kvinders brug af kirken i Singapore sammenlignes med, hvordan for eksempel filippinske immigranter i Houston bruger deres lokale kirke (Cherry 2008).

Den danske sømandskirke i Singapore er ikke speciel blandt danske kirker i udlandet. I den danske sømandskirke i Rotterdam står præsten og hendes hjælpere for en fredagsbar i kirken, og mere end tyve unge danskere møder regelmæssigt op. ${ }^{5}$ I Melbourne og Sydney spillede de danske kirker en vigtig rolle ved at oprette og huse en dansk søndagsskole, hvor danske immigranters børn kunne lære dansk. ${ }^{6}$ I Bruxelles har kirken særlige sammenkomster for de mange danske au pair piger i byen. I det hele taget synes vægtningen mellem religiøse og verdslige aktiviteter i danske kirker i udlandet at hælde betydeligt mere mod den verdslige side, end hvad der normalt er tilfældet i en gennemsnitlig evangelisk-luthersk sognekirke i Danmark.

\section{Et nationalt-religiøst rum}

Den danske sømandskirke i Singapore er dog ikke en dansk selskabelig forening i et fremmed land, selv om den lægger hus til mange fælles arrangementer af social ka-

Interview med pastor Line Nicolaisen, Rotterdam, 9. november 2010.

www.danishschooldownunder.org.au/content/history (set 28.6.2011). 
rakter. Villaen er så absolut et sted, der signalerer både kirke og Danmark. Hovedrummet har en åben tværfløj, der er møbleret som en kirkesal med et alter henne ved vinduet. Som i næsten alle danske kirker hænger der et kirkeskib ned fra loftet. Det karakteristisk danske rum er også markeret gennem forskellige genstande, som klart henviser til Danmark. Lamperne er danske PH-lamper, et af ikonerne fra moderne dansk designs gyldne periode, højttalersystemet er af det anerkendte danske mærke Bang \& Olufsen, der er billeder fra forskellige danske lokaliteter, der er opslagstavler med beskeder på dansk, en liste med navne på danske skibe i havn osv. Denne kombination af kirkerum og et karakteristisk dansk rum gør villaen til et dansk nationaltreligiøst rum.

\section{Helligt og verdsligt rum}

I de evangelisk-lutherske kirker i Danmark er der tradition for, at selve kirkerummet er forbeholdt gudstjenester, og bortset fra nogle få særlige typer arrangementer såsom koncerter kan en eventuel verdslig brug af kirkerummet være et kontroversielt emne. Verdslige aktiviteter, der organiseres af kirken, foregår derfor som regel i tilstødende lokaler til selve kirkerummet. Denne forskel i brugen af kirkens fysiske rum afspejler blandt andet, at det er en generel opfattelse, at kirkerummet hører til en særlig kategori af rum. Set fra et religionshistorisk perspektiv drejer det sig om den klassiske opdeling mellem det hellige (sakrale) og det verdslige (profane). Kirkerummet er et helligt rum modsat et profant eller verdsligt rum. Denne opdeling understøttes dog ikke af den lutherske dogmatik, der ikke i sig selv tilskriver en bygning eller et andet rum en særlig hellighed, men mange mennesker synes alligevel, at det er sådan.

Adskillelsen mellem det hellige og det verdslige rum er ikke så skarp i kirken i Singapore, hvor hovedrummet bruges både til gudstjenester og til forskellige verdslige aktiviteter. De regelmæssige søndagsgudstjenester foregår i den tværfløj, der er indrettet som en kirke, men ved juletid er der ikke nok stole i denne del af bygningen, og resten af hovedrummet tages i derfor i brug. Ved andre lejligheder bruger menigheden rummet, der normalt benyttes til gudstjenester, til forskellige arrangementer, som man normalt ville opfatte som verdslige - først og fremmest den årlige julebasar.

Denne udviskning af skellet mellem helligt og verdsligt rum rummer nogle iboende konflikter. Som et eksempel havde den danske menighed i byen La Dulce i Argentina erhvervet en bygning med henblik på at bruge den både som kirke og som forsamlingshus til fester og anden verdslig brug. Men ved en familiefest, hvor gæsterne ønskede at danse, protesterede et medlem af menigheden mod dette og fastslog, at "det rum, hvor min fars kiste har stået, skal ikke bruges til dans!"7

I en anden menighed i Argentina i San Cayetano var der ved at opstå den samme konflikt over brugen af kirkerummet, da den lokale danske menighed i slutningen af

7 Interview med pastor Steen Lerfeldt, Necochea, 1. februar 2010 og e-mail 5. juli 2010. 
1990'erne ønskede at kombinere kirkelige og verdslige sociale aktiviteter i ét, nyt stort rum. Den opfindsomme præst løste problemet ved at etablere en fleksibel væg, som kunne skjule alteret, der var placeret i en trekantet apsis, når rummet var i verdslig brug. Derved blev alle tilfredse. ${ }^{8}$ Løsningen var et kompromis mellem den almindelige, folkelige opfattelse, at et kirkerum er 'anderledes', også når der ikke afholdes gudstjenester i det, og det standpunkt, som deles af de fleste danske teologer, at kirken er etableret, når man samles i menigheden og hører Guds ord.

I Rotterdam er den årlige julebasar en vigtig indtægtskilde, ligesom den er for alle danske kirker i udlandet. I fire dage fylder basaren al tilgængelig plads på kirkens område inklusive et ekstra telt uden for bygningen og også selve kirkesalen. Efter en lang basardag den 6. november 2010 spiste præsten og alle medhjælperne på restaurant, og jeg blev indbudt til at tage med. Under middagen sagde præsten, at hun hellere måtte sørge for, at kirkesalen så hurtigt som muligt vendte tilbage til sit normale udseende. Hun tilføjede spøgefuldt, at det måske ville hjælpe at stænke rummet med vievand. Med denne bemærkning anerkendte hun den almindelige opfattelse af, at et kirkerum er et helligt sted, og at der var behov for at gendanne rummets sakrale tilstand efter dets brug til julebasar. Ved netop at nævne det at stænke med vievand, som er en katolsk og ikke en luthersk skik, viste hun også på en fin måde, at hun ikke selv delte denne opfattelse.

\section{Stat, civilsamfund og erhverv}

De danske kirker i udlandet er selvstændige foreninger, som ledes af lokalt valgte bestyrelser. Den danske stats indflydelse er dog stor: Hvert år modtager kirkerne statsstøtte gennem paraplyorganisationen, Danske Sømands- og Udlandskirker, og de udsendte præster er ansat i den danske folkekirke.

Også lokalt støttes de danske kirker af den danske stat. I Singapore udveksler for eksempel den danske ambassade og kirken regelmæssigt lister med navne og e-mailadresser, foldere fra kirken ligger fremme på ambassaden, og endelig er ambassadøren medlem af kirkens bestyrelse og skriver som regel en spalte i kirkebladet. En verdslig dansk klub ville ikke få samme støtte og ville udelukkende være afhængig af frivilligt arbejde og penge betalt af det lokale danske civilsamfund. Det er derfor næppe overraskende, at for eksempel i Singapore er den eneste levedygtige danske klub Danish Business Association of Singapore, hvor medlemskabet betales af de danske virksomheders lokale kontorer i Singapore.

Sammenhørigheden mellem kirke og stat stopper ikke med disse eksempler. Ligesom flere af hendes kolleger har præsten i Rotterdam diplomatisk status som ulønnet social attaché, hvilket blandt andet medfører, at ambassaden af og til beder hende om at besøge danskere, der er blevet anholdt og sidder fængslet i Holland. Efter præstens

8 Interview med pastor Steen Lerfeldt, Necochea, 1. februar 2010 og e-mail 5. juli 2010. 
opfattelse havde disse danskere dog som regel mere brug for en advokat end en præst, for slet ikke at nævne den lille detalje, at hovedparten af de fængslede er muslimer. I realiteten servicerer kirken danske borgere i Holland på adskillige måder, foruden at den varetager deres religiøse behov. I følge den danske præst er det især blevet tilfældet, efter at ambassaden i Holland ligesom andre danske ambassader inden for EU ikke yder danske borgere samme service, som de gjorde tidligere. Som præsten sagde: "Vi er den danske ambassade i dagligdagen". 9

Den danske stats støtte til kirkerne i udlandet giver kirkerne en betydelig ekstra prestige, og den følgende hændelse, som jeg fik fortalt af præsten i Buenos Aires, er meget sigende i den henseende: Den lokale danske menighed havde aftalt at ansætte en ny præst, der var dansk-argentiner, og hvis uddannelse var blevet delvis betalt af menigheden. Præsten var homoseksuel, og det vidste menighedsrådsformanden. Men det lykkedes alligevel en konservativ fraktion i menighedsrådet at overtale formanden til mod aftalen ikke at ansætte præsten. Da den danske ambassadør blev opmærksom på sagen, greb han ind, selv om han formelt ikke havde noget ansvar for kirken, og den danske stat heller ikke betalte præstens løn. Ambassadøren meddelte simpelthen menighedsrådet, at hvis de ikke accepterede at ansætte præsten, ville ambassadøren boykotte kirken. Det indebar blandt andet, at han ikke ville følge traditionen med at åbne kirkens julebasar, og menighedsrådet ville heller ikke længere blive inviteret til et glas vin på ambassaden i anledning af dronningens fødselsdag. Da de blev stillet over for denne ildevarslende trussel, overgav de konservative menighedsrådsmedlemmer sig, og præsten fik den stilling, han oprindeligt var blevet lovet. Sagen viser, hvor betydningsfuldt det er for en dansk kirke i udlandet at nyde den danske stats gunst, selv på det rent symbolske plan.

Støtten fra erhvervslivet til udlandskirkerne er vigtig for kirkernes drift. I Singapore afholder Danish Business Association of Singapore sin årlige julefrokost i kirkens lokaler, foreningen betaler for de danske aviser i kirken, og andre store danske virksomheder støtter kirken økonomisk. ${ }^{10}$ Store danske rederier, særligt Mærsk og Torm, giver regelmæssigt betydelige gaver og støtte til danske sømandskirker, for eksempel forærede Torm en ny bil til kirken i Singapore.

Små og store bidrag fra virksomheder er også vigtige for julebasarernes økonomi. I Rotterdam havde prins Joachims gods Schackenborg for eksempel foræret seks flasker specialsnaps, der blev udstillet på basaren på en hylde i kirkesalen, lige der hvor alteret plejede at stå. Det var et symbolsk møde mellem kirke, erhvervsliv og kongefamilie i en dansk kirke i udlandet.

9 Interview med pastor Line Nicolaisen, Rotterdam, 9. november 2010.

10 Læs mere om Danish Business Association of Singapore på www.dabs-singapore.com/script/site/default.asp (set 28.6.2011) 


\section{Den danske sømandskirke i Singapore og dansk offentlig sfære}

På hjemmesiden for den danske ambassade i Singapore opregner ambassadøren i sin velkomsthilsen ambassadens forskellige opgaver. ${ }^{11}$ Velkomsthilsnen slutter med følgende ord:

\footnotetext{
Det er min og medarbejdernes ambition, at ambassaden skal være et lille stykke Danmark i Singapore, åben for alle danskere. Vi lægger derfor vægt på at pleje gode forbindelser til den betragtelige danske koloni på ca. 1.500 personer.

I opfyldelse heraf virker ambassaden nært sammen med den Danske Sømandskirke i Singapore og Danish Business Association (DABS).
}

Pastor Hans Vestergaard Jensen havde et rammende udtryk for denne tætte forbindelse mellem ambassaden, kirken og den danske erhvervsforening: “Kirken, ambassaden og Danish Business Association of Singapore udgør den hellige treenighed i Singapore". ${ }^{12}$

Med udgangspunkt i dette citat vil jeg hævde, at den danske sømandskirke i Singapore påtager sig en rolle som den lokale danske offentlige sfære i Singapore. Her ser vi staten (ambassaden), erhvervslivet og det lokale danske civilsamfund i interaktion. Disse tre aktører kan gekendes fra Jürgen Habermas' analyse af den offentlige sfære, men her er de anvendt på mikroniveau, dvs. sømandskirken, ikke på det statslige niveau (Habermas 1989). Civilsamfundet er i Habermas' forståelse summen af borgernes frivillige, fælles handlinger ansporet af deres fælles interesser og ikke ved tvang fra statens side.

Habermas' analyse af den offentlige sfære tager udgangspunkt i Oplysningstidens politiske og filosofiske kritik af enevælden. Med denne kritik, som fandt sted i en offentlig, men ikke-statslig sfære, opstod der i Vesten en tradition for borgerlig debat i civilsamfundet, som skabte grundlaget for demokrati efter vestlig opfattelse. I det moderne samfund er den offentlige sfære dog blevet mere og mere sammenflettet med staten og også i stigende grad blevet påvirket af massemedier og kommercielle interesser (Habermas 1989, 181-235).

Civilsamfundets, statens og erhvervslivets tresidige indflydelse på den danske kirke i Singapore kan illustreres med følgende model (se næste side).

1 www.ambsingapore.um.dk/da/menu/OmOs/Velkommen/ (set 28.6.2011).

12 Interview med pastor Hans Vestergaard Jensen, Singapore 24. august 2008. 


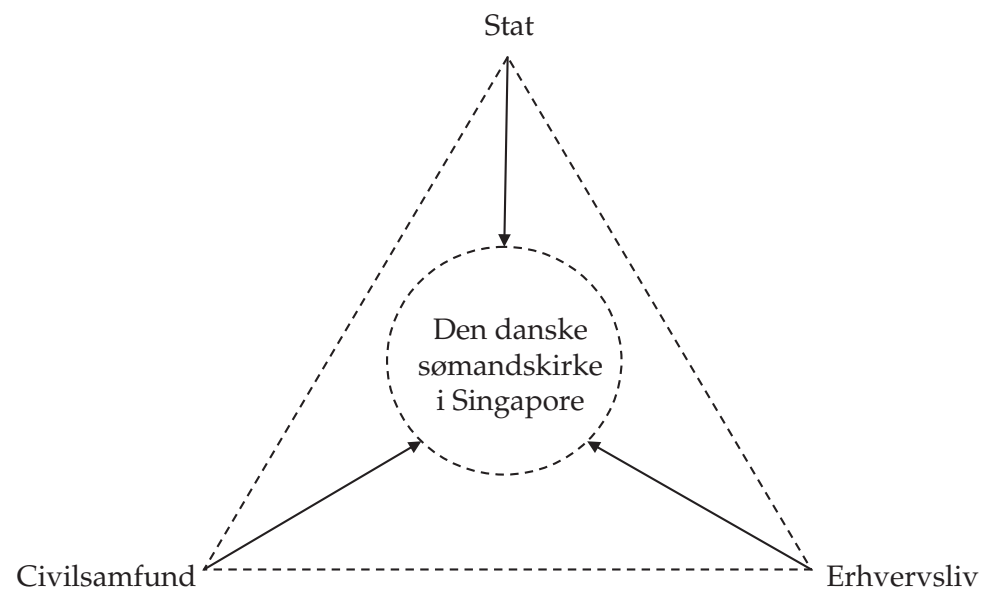

Fig. 1 Den danske sømandskirke i Singapore mellem civilsamfund, stat og erhvervsliv

Efter denne model udfylder den danske sømandskirke en rolle som den lokale danske offentlige sfære i Singapore. Først og fremmest er den det eneste danske rum, som giver alle danskere i Singapore mulighed for et regelmæssigt socialt samvær, og kirken har som nævnt opnået et næsten-monopol på at være det danske rum i Singapore. Her kan folk møde hinanden ved de forskellige kirkearrangementer, diskutere sager, der er af interesse for det danske immigrantsamfund og forsøge at påvirke dem, der leder kirken (præsten og kirkens bestyrelse), og dem der har adgang til økonomiske støttemuligheder, dvs. medlemmer af Danish Business Association of Singapore. Kirken er også det sted, hvor man kan læse danske aviser på fax og følge med i dansk indenrigspolitik og andre anliggender, der måtte vedrøre danske borgere. Endelig betyder den tætte kontakt med ambassaden, at de af immigranternes synspunkter, der anses for at være relevante, kan viderebringes til det danske politiske system på uformel vis. Så selv om danske immigranter ikke kan udøve deres borgerret ved at stemme, har de gennem kirken en kanal til indflydelse. ${ }^{13}$

Der er ingen tvivl om, at sammensmeltningen af civilsamfundets, erhvervslivets og den danske stats interesser er meget udtalt i kirken i Singapore. Men mønsteret vil man også kunne genkende i de andre udlandskirker.

13 Kirken er naturligvis ikke den eneste kanal til indflydelse. Danske immigranter er ofte medlemmer af danske immigrationsforeninger, netværk og lobbyorganisationer og har henvendt sig til de danske myndigheder og politikere med to større anliggender, der vedrører udlandsdanskere: suspenderingen af stemmeretten efter seks måneders ophold i udlandet og det danske forbud mod dobbelt statsborgerskab. Der er en igangværende kampagne for at tillade dobbelt statsborgerskab, se www.statsborger.dk (set 28.6.2011). 


\section{Konklusion}

Mine studier af flere danske kirker i udlandet viser, at foruden at varetage de traditionelle religiøse ydelser har kirkerne også en vigtig funktion som et socialt samlingssted for det lokale samfund af danske immigranter - både midlertidige og permanente immigranter. Kirkerne giver danskerne en mulighed for samvær i et særligt dansk miljø, og i den henseende ligner de andre immigranters religiøse institutioner. De mange og forskellige aktiviteter, der arrangeres af de danske kirker, betyder, at kirkens lokaler ofte bruges til ikke-religiøse formål. Præstens spørgeskemaundersøgelse i Singapore viste, at mange danskere i Singapore, måske endda flertallet, anså kirkens ikke-religiøse aktiviteter for at være de mest relevante for dem.

Udlandskirkerne har dog som regel problemer med begrænset plads, og det medfører, at det hellige og det verdslige rum ikke holdes strengt adskilt, men ofte er forenet $i$ et fælles dansk nationalt-religiøst rum. Det krænker imidlertid af og til almindelige folkelige opfattelser af, at det er vigtigt at holde det hellige rum adskilt fra det verdslige, sådan som eksemplerne fra Rotterdam og to argentinske kirker har vist.

De stærke bånd til den danske stat giver den danske sømandskirke i Singapore og andre danske kirker i udlandet en usædvanligt favorabel stilling. Med inspiration i Habermas' forståelse af den offentlige sfære har jeg foreslået en model, der illustrerer, at kirken har udviklet sig til at blive en lokal dansk offentlig sfære, hvor alle danske aktører i Singapore inklusive ambassaden og det lokale danske erhvervsliv kan påvirke hinanden. Ligesom i offentlige sfærer generelt ser man i de danske kirker i udlandet, hvordan alle tre delelementer af et moderne samfund, nemlig stat, erhvervsliv og civilsamfund, vekselvirker med hinanden.

\section{LITTERATURLISTE}

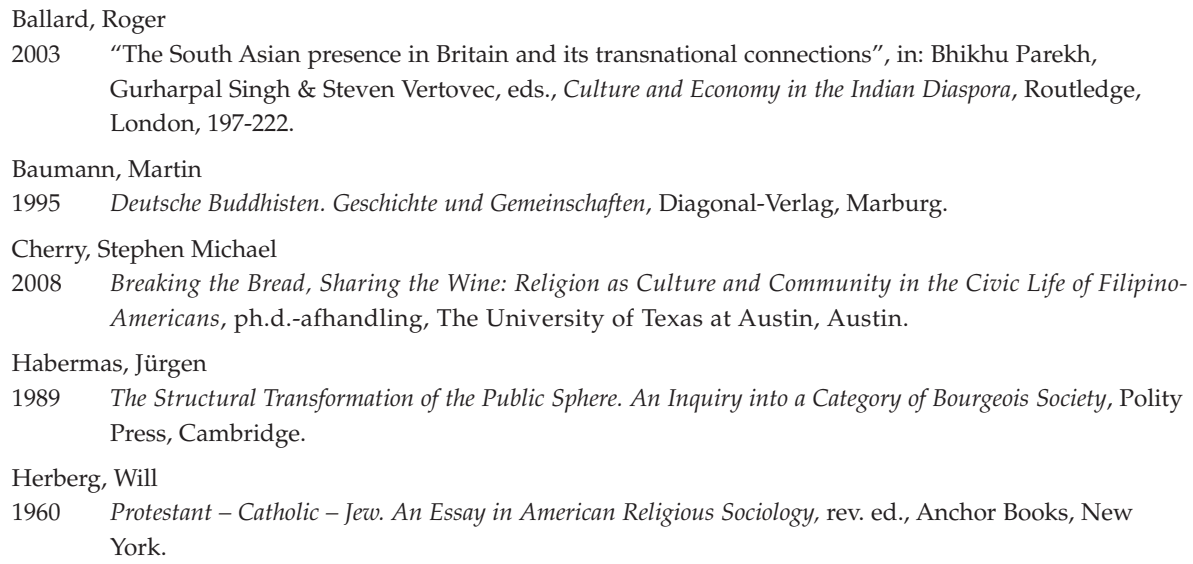


Hirschman, Charles

2004 "The Role of Religion in the Origins and Adaptation of Immigrant Groups in the United States", in: International Migration Review 38, 1206-1233.

Jacobsen, Brian A. \& Margit Warburg

2011 "... og dog så vidt om jorden: Udlandsdanskere sammenlignet med danskere i Danmark", in: Peter Gundelach, ed., Små og store forandringer. Danskernes værdier siden 1981, Hans Reitzel, København, 264-283.

Jensen, Hans Vestergaard

2006 "Resultat af undersøgelse 2006", PowerPoint-præsentation (ikke udgivet).

2010 "Et værn om identiteten", in: Jan Lund, ed., Den Gyldne Klokke. 25 år med Den Danske Sømandskirke $i$ Singapore, Den Danske Sømandskirke i Singapore, Singapore, 48-51.

Kühle, Lene

2006 Moskeer i Danmark - islam og muslimske bedesteder, Univers, Højbjerg.

Levitt, Peggy

2004 "Conceptualizing Simultaneity: A Transnational Social Field Perspective on Society", International Migration Review 38, 1002-1039.

2007 God Needs No Passport. Immigrants and the Changing American Religious Landscape, The New Press, New York.

Pedersen, Esther \& Eskild Pedersen

2010 "Sømandskirke i troperne", in: Jan Lund, ed., Den Gyldne Klokke. 25 år med Den Danske Sømandskirke i Singapore, Den Danske Sømandskirke i Singapore, Singapore, 37-47.

Pedersen, Ronald

2010 “Kirke i romantisk eventyrslot”, in: Jan Lund, ed., Den Gyldne Klokke. 25 år med Den Danske Sømandskirke i Singapore, Den Danske Sømandskirke i Singapore, Singapore, 17-28.

Simonsen, Henrik Bredmose

1990 Kampen om danskheden. Tro og nationalitet i de danske kirkesamfund i Amerika, Aarhus Universitetsforlag, Århus.

Warburg, Margit

"A Danish National-Religious Space Abroad", in: Esther Fihl \& Jens Dahl, eds., Alternative Spaces (under udgivelse).

Warner, R. Stephen

1998a "Immigration and Religious Communities in the United States", in: R. Stephen Warner \& Judith G. Wittner, eds., Gatherings in Diaspora. Religious Communities and the New Immigration, Temple University Press, Philadelphia, 3-34.

1998b "Religion and Migration in the United States", Social Compass 45, 123-134.

Yang, Fenggang \& Helen Rose Ebaugh

2001 "Transformations in New Immigrant Religions and Their Global Implications", American Sociological Review 66, 269-288.

Margit Warburg, professor, dr. phil. Institut for Tværkulturelle og Regionale Studier Københavns Universitet 